\title{
Revisiting the link between business strategy and performance: Evidence from hotels
}

\author{
María Rosario González-Rodríguez ${ }^{\mathrm{a}}$, José Luis Jiménez-Caballero ${ }^{\mathrm{a}}$, \\ Rosario Carmen Martín-Samper ${ }^{\mathrm{a}}$, Mehmet Ali Köseoglu ${ }^{\mathrm{b}, *}$, Fevzi Okumus $^{\mathrm{c}}$

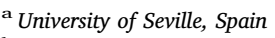 \\ ${ }^{\mathrm{b}}$ School of Hotel and Tourism Management, The Hong Kong Polytechnic University, Hong Kong SAR \\ ${ }^{\mathrm{c}}$ Rosen College of Hospitality Management, University of Central Florida, Orlando, FL, United States
}

\section{A R T I C L E I N F O}

\section{Keywords:}

Position-based view

Resource-based view

Hotels

Spain

\begin{abstract}
A B S T R A C T
This paper aims to investigate the competitive success factors for hotel companies and examine the link between business strategy and performance. Using a structured questionnaire, the researchers collected data from hotel managers in Spain. Study results suggest that a firm's assets and strategies have a greater influence on performance than industry forces do. This lack of direct influence by industry forces is due to the sector's specific characteristics, which cannot be overlooked during analysis. Based on these research findings, theoretical and managerial implications and future research are presented.
\end{abstract}

\section{Introduction}

The present study aims to analyze and identify the strategy factors driving the performance of hotels. Several studies have examined how managers formulate and implement business strategies to gain sustainable competitive advantages (Durand et al., 2017; Furrer et al., 2008; Hoskisson et al., 2013) in their markets. Scholars suggest that, when formulating or implementing strategies, managers should focus on the external environment, called the position-based view (Porter, 1985); or the internal environment, called the resource-based view (RBV) (Barney, 1991). These studies claim that no approach fully explains a company's performance or the success of a single strategy (Lam et al., 2015). Grant (2016) suggests that companies should combine these two approaches to gain sustainable competitive advantages. However, because of the ongoing debate concerning these approaches (Parnell, 2006), combining them has not been adequately considered or executed when formulating and implementing competitive strategies (Armanios et al., 2017; Brenes et al., 2016; Hoskisson et al., 2000).

Scholars have advised managers in the hospitality industry to follow either the position-based view (Chathoth and Olsen, 2007), resourcebased view (Claver-Cortés et al., 2007; Marco-Lajara et al., 2016), or both views simultaneously (Koseoglu et al., 2013; Lam et al., 2015; Pereira-Moliner et al., 2015). Some specific characteristics of hotel companies, such as the lack of inventory and the fact that production and consumption coincide in space and time (the servuction process) require special capabilities in employees. In the servuction process, both clients and employees can modify the services provided and their cost. Thus, applying these two approaches in the hotel industry may play an important role both in the formulation and implementation of competitive strategies (Koseoglu et al., 2013; Koseoglu et al., 2016). Consequently, to clarify key success factors, more studies examining how the application of both approaches simultaneously impacts hotel performance are needed. The present study addresses the relationship between business strategy and firm performance in hotels by examining the following research questions: What is the structure of the relationship between business strategies and firm performance, including market performance and profitability? What factors-industry forces, firm assets, or both-drive firm performance? How do these factors influence firm performance?

Through a literature review, the position-based view and the resource-based view are examined, to explain both their competitive success related to hotels and the research model which integrates both approaches. Following this, the research design and methodology of this study are discussed. The results achieved by estimating the research model by Partial Least Square are then shown. After discussing the primary results of this research, relevant conclusions, as well as theoretical and managerial implications, are drawn from the findings. In the final section, certain limitations are recognized that, in turn, shed light on future avenues of research.

\footnotetext{
* Corresponding author.

E-mail addresses: rosaglez@us.es (M.R. González-Rodríguez), jjimenez@us.es (J.L. Jiménez-Caballero), rmartin@us.es (R.C. Martín-Samper), Mehmetali.koseoglu@polyu.edu.hk (M.A. Köseoglu), fevzi.okumus@ucf.edu (F. Okumus).
} 


\section{Literature review}

Before the 1980s, business strategy aimed to detect the needs of the market and, subsequently, acquire the technological capability and resources required to address them. To address globalization, a company must differentiate itself from its competition and offer products with exclusive added value (Yin-Hsi, 2012). To do this, an organization must leverage the permanent assets it has amassed from experience, which cannot easily be replicated by the competition. The company must adopt a business strategy that engages with the evolving environment and market in which it operates while considering and maintaining coherence with its own resources. In this respect, two mutually complementary theories exist: Porter's theory of competitive forces, which gives priority to aspects of the industry the company operates within; and resources and capabilities theory, which focuses on a company's potential for achieving a competitive advantage, given the internal resources that lead it to select as yet unexploited opportunities. According to Spanos and Lioukas, (2001), Bridoux (2004), and Yin-Hsi (2012), the two theories complement and enhance one another by providing a company with both the internal and external analyses required to survive and perform well in a competitive environment.

\subsection{Porter's framework and $R B V$ in the manufacturing industry}

Some authors believe that environment determines a company's results. In his study of industrial organizations, Bain (1959) measured and analyzed the variables that shape the competitive market structure a company operates within and the company's interrelationship with its competitors. According to this study, a sector's structure determines its economic-financial results, meaning that a company has no influence over its own results. Mason (1949) also maintained that the structural forces of a sector steer the actions of a company's manager. In organizational theory, Hannan and Freeman (1977) likewise highlight the environment's determinant role.

Hannan and Freeman were forerunners of the competitive-forcesbased paradigm that Porter (1980) developed during the 1980s: the Strategic Approach. In this approach, a firm develops defensive strategies to counter environmental forces (Porter, 1985, 1991), meaning that the structure of the market determines the position the company should adopt. Thus, the company is in a state of constant adaptation, seeking the set of strategic activities that will enable it to obtain the best performance. The goal of this school (position-based view) of thought is to create at least one of the three types of business-level strategies leading to competitive advantage: differentiation, low-cost strategy, or focus strategy (Hamdan, 2017; Notta and Vlachvei, 2017).

The second school of thought, the resource-based view (RBV), claims the organization's internal resources determine its performance (Barney, 1991). This view assumes that the resources and capabilities used by a company in its strategies must be heterogeneous and nontransferrable from one company to another, thus helping the business differentiate from its competitors. The RBV states that a sustainable competitive advantage is determined by an organization's resources (Hitt et al., 2016; Kellermanns et al., 2016; Kull et al., 2016). Several studies claim that company-specific resource characteristics, such as uniqueness, evaluability, sustainability, and capability, lead to superior performance (Backman et al., 2017; Darcy et al., 2014; Lockett and Wild, 2014; Mahoney and Pandian, 1992; Schroeder et al., 2002). These resources may be tangible (i.e., physical and financial resources) and intangible (Dodd, 2016; Greco et al., 2013; Grant, 2016; Stead and Stead, 2016). At the firm level, there are four types of intangible resources: intellectual property assets, the interest and importance of which are based on a sustainable competitive advantage provided by a legal mechanism to protect property rights (Hoopes et al., 2003); organizational assets (Brooking, 1996); reputational assets (Day and Wensley, 1988; Srivastava et al., 2001) leading to sustainable economic benefits; and capabilities, meaning the skills necessary for appropriately managing these resources (Grant, 2016).

Although these two schools of thought may be considered rivals, in practice, businesses need to consider both external and internal environments simultaneously when formulating and implementing business strategies, as performance depends on the fit between the capabilities and resources of an organization, and its environmental contingencies based on contingency theory (Balkin and Gomez-Mejia, 1987; Dikova et al., 2017; Shirokova et al., 2016). Depending on the situation-including market structure, the intensity of competition, industrial differences, the type of economy, the industry life-cycle, the level of uncertainty, and cultural differences (Fernández-Olmos and Ramírez-Alesón, 2017)—organizations can focus on one or more strategies (McAdam et al., 2016; Phillips, 1999; Spanos and Lioukas, 2001; Turner et al., 2017). Hence, these two perspectives are complementary to each other. Conner (1991), Mahoney and Pandian (1992), and Teece et al. (1997) investigated the stated premises of the RBV in relation to market power and types of rents. They proposed a dynamic-capabilities approach for competitive advantages and superior performance. This approach goes beyond the static RBV when incorporating market dynamics (Ambrosini and Bowman, 2009; Eisenhardt and Martin, 2000). The dynamic-capabilities view focuses on exploiting a company's specific external and internal environment to quickly adapt to changes faster than its competitors can (Barros et al., 2016; Teece et al., 2016). The above studies suggest that no single school of thought fully explains company performance and the success of choosing a single strategy action. Based on these discussions, the following integrated research model (Fig. 1) might be developed. This multidirectional model incorporates the following effects, which are essential for achieving competitive success: 1 ) the effects of strategy actions, industry forces, and firm assets on competitive success; and 2) the indirect effects of firm assets on competitive success via strategy actions and the indirect influence of strategy actions on competitive success via industry forces, which would provide suitable conditions for any competitive advantage to remain sustainable.

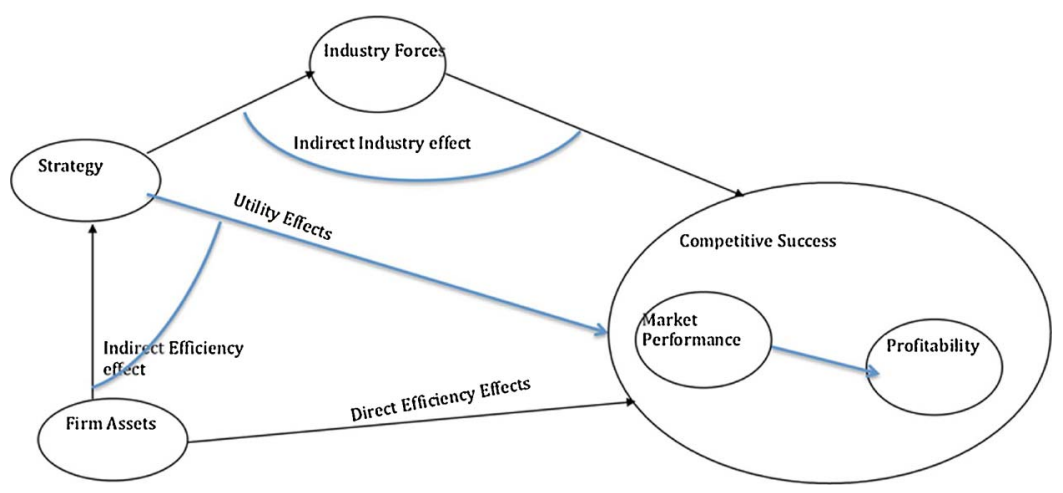

Fig. 1. Research Model: Integrated approach for business strategy (Spanos and Lioukas, 2001). 


\subsection{Porter's framework and RBV in hotel industry}

Several studies have investigated the link between strategy and firm performance in the hotel industry (Koseoglu et al., 2013; Ramanathan et al., 2016). Koseoglu et al. (2013) found that hotels in Turkey seeking to combine the low-cost and differentiation approaches are likely to end up stuck in the middle. Ramanathan et al. (2016) showed how the RBV impacts hotel performance in hotels located in the United Kingdom. They suggested that managers should consider improving operations and environmental capabilities by exploiting the synergies between them, rather than by focusing on marketing activities. However, based on the authors' knowledge, no previous study has empirically investigated both the positioning and resource-based views simultaneously in the hotel industry, although there are studies focusing on business strategies from the positioning approach or the RBV in the hospitality and tourism industries (Chathoth and Olsen, 2007), or from the perspective of other business strategies, like the Miles and Snow typology (Avci et al., 2011; Garrigós-Simón et al., 2005; Lo, 2012), in the hospitality industry. These studies found a significant relationship between the components of strategy and performance; however, they did not analyze, either directly or indirectly, the relationship between the duality of strategy components, including using both the positionand resource-based views simultaneously in the hotel industry to gain more understanding on formulation and implementation of competitive strategies.

As mentioned earlier (Fig. 1), industry forces have an impact on firm performance. For example, Law et al. (2015) analyzed the link among industry forces, strategic implementation, and performance in stateowned hotels in China. They found that industry forces play a critical role in the strategic development of the hotels. Competitors, customers, and new hotel entrants have a stronger impact on performance than substitutes and suppliers have. Therefore, the following hypotheses $(\mathrm{H})$ are proposed concerning the relationship between industry forces and firm performance:

H1. Firm performance, as perceived by hotel managers, is influenced by the industry forces variable (i.e., competitive rivalry).

H1a. Industry forces have a significant direct influence on firm performance (i.e., market performance and profitability).

H1b. Market performance mediates the relationship between industry forces and firm performance.

In the literature, many studies (Kraaijenbrink et al., 2010; Kull et al., 2016; Lin and Wu, 2014) address how firm resources influence firm performance. For example, Leonidou et al. (2013) highlighted resources as very important drivers for hotel environmental marketing strategies and firm performance in the Greek hotel industry. Therefore, the following hypotheses concerning the relationship between firm resources and firm performance, based on responses from hotel managers, are proposed:

H2. Firm performance, as perceived by hotel managers, depends on firm assets (both intangible and tangible resources).

H2a. Firm assets have a direct influence on firm performance, including market performance and profitability.

H2b. The relationship between firm assets and firm performance is also mediated by the strategy followed by the hotel.

Assertions about the superiority of one approach over another are constantly updated as new formulae and strategies are discussed and implemented. Paladino et al. (2015) summarized these discussions and indicated the orientations of internal and external organizations by comparing the RBV and position approach. Based on these discussions, the authors propose a third hypothesis:

H3. Firm performance, as perceived by hotel managers, depends on the strategy chosen by the hotel (i.e., marketing differentiation, innovation differentiation, low-cost).

H3a. The strategy followed by the hotel has a direct influence on firm performance.

H3b. Industry forces mediate the relationship between strategy and firm performance.

\section{Methodology}

\subsection{Development of research instruments}

As seen in Appendix A, multi-item, seven-point Likert scales were used to measure industry forces, firm assets, strategy, and firm performance. Firm performance was treated as a two-dimensional construct: profitability and market performance. Profitability and market performance were measured using the scale established by Spanos and Lioukas (2001). Thus, profitability was measured by answering the question: "Please indicate your firm's position compared to the competition for each of the following items during the last three years ( 1 = well below average to $7=$ well above average): 1 ) profit margin, revenue per available room (RevPar); and 2) net profit (see Appendix A). Market performance was measured by answering the question: "Please indicate your firm's position compared to the competition for each of the following items during the last three years ( 1 = Well below average to $7=$ Well above average): 1 ) sales volume, 2 ) growth in sales volume, 3) market share, and 4) growth in market share (see Appendix A). The two dimensions of firm performance-profitability and market performance-were included in the model, as most empirical studies indicate that market performance has a significant positive effect on firm profitability (Galbreath and Galvin, 2006).

The measurement of industry forces seeks to capture the concept of competitive forces, as introduced by Porter (1980). The study focused on the competitive rivalry force used by managers to create and sustain the competitive advantage that affords a company an above-average firm performance. Competitive rivalry was measured using the validated scale adapted from Achrol and Stern (1988). The measurement refers to the specific position of the hotel with respect to its market. Thus, hotel managers were asked to answer the following question: "How would you evaluate the intensity of the competition ( 1 = Very weak competition to $7=$ Very strong competition) that your firm is facing with respect to the following items: service strategy characteristics, product characteristics, hotel's physical characteristics, promotional strategies, and access to distribution channels?" The selected items refer to the peculiarities of the hotel sector (AECA, 2013).

Once managers determine the threats and opportunities existing in their operating environment, the appropriate competitive strategy must be selected. The measurement scales for Porter's generic strategies-competitive strategies for marketing differentiation, innovation differentiation, and low-cost strategy-were derived from Miller (1988). The items defining those strategies were drawn from the Spanish Hotel Technological Institute report (Spanos and Lioukas, 2001). Senior hotel managers were asked: "Please indicate the degree to which you use the following strategies ( 1 = Much less than our competitors to $7=$ Much more than our competitors): 1) differentiation based on delivering a qualitative service to a select market; 2) low cost production to offer an economic and accessible service to a wider market; 3) modernization and automation of a production and commercialization process; and 4) innovations in marketing, product innovation, and process innovation." These were included in the analysis as three first-order constructs, as hotels can pursue competitive advantage through a range of different strategies.

Firm assets were defined as a higher-order construct that, following empirical studies like Galbreath and Galvin (2006) and Spanos and Lioukas (2001), included organizational, marketing, technical, and 
Table 1

Profile of Participating Hotels and Managers.

\begin{tabular}{lll}
\hline Operating Regime (\%) & Property & 30.40 \\
& Management & 19.60 \\
& Rental & 41.00 \\
& Franchise & 6.50 \\
& Other & 2.20 \\
Chain (\%) & Yes & 69.60 \\
& No & 30.4 \\
Stars (\%) & 3 & 25 \\
& 4 & 60 \\
Family group (\%) & 5 & 15 \\
HM gender (\%) & Yes & 50.00 \\
& No & 48.90 \\
HM age (\%) & Male & 68.00 \\
& Female & 26.10 \\
& Under 25 & 0.00 \\
& $26-35$ & 28.30 \\
HM experience (years) & $36-50$ & 55.40 \\
& over 50 & 16.30 \\
& Min. & 2 \\
\hline
\end{tabular}

reputational capabilities. To measure these dimensions, hotel managers were asked to respond to the following question: "Please indicate the strength of each of the following resources for your firm compared to the competition $(1=$ Much weaker than the competition to $7=$ Much stronger than the competition)."

Organizational assets included managerial expertise, cultural climate, strategic planning, efficient organizational structure, coordination of the hotel's hierarchy, hotel employee skills and know-how, and the ability to attract creative employees (Spanos and Lioukas, 2001). Marketing capabilities consisted of four items (Lado et al., 1992; Spanos and Lioukas, 2001): market knowledge, control and access to distribution channels, advantageous relationships with customers and suppliers, and a strong customer base. Technical capabilities were defined by the technological resources available to the organization (e.g., a centralized booking system, intranet, e-booking), hotel equipment, and geographical location (Leonard-Barton, 1995; Spanos and Lioukas, 2001). Reputational assets included the firm's customer service reputation and the company's reputation with respect to social and environmental responsibility (Spanos and Lioukas, 2001). Firm size (i.e., the number of employees) is a common control variable used to eliminate any effects on firm performance this might have on firm performance (Spanos and Lioukas, 2001).

\subsection{Data collection and sample}

Data were collected from hotel managers of three- to five-star hotels in both the city of Seville and in the Seville province (Andalusian region) in Spain. The questionnaire included multi-item, seven-point Likert scale questions about aspects of intangible assets, strategies, competitive positioning, and firm performance. Other typical variables for hotel businesses were included, such as size (the number of employees, capacity measured by number of rooms), operating regime (ownership, management, rental, franchise, other), type (chain, family business), family group hotel (with more than $50 \%$ of the capital), and hotel manager-related variables (gender, age, and years of experience). The study population comprises the 127 hotels registered with the Seville Hotel Association, 100 of which are in the midscale-to-luxury category (with three, four and five stars). The data collection process was completed through telephone surveys. However, the survey was initially sent online, so that senior hotel managers could have a copy of the survey at hand during the interview. According to Díaz de Rada (2012), telephone surveys allow interviewers access to the whole population and to make more than one attempt to contact the respondents. Phone calls provide access to very busy or difficult to locate individuals, such as senior hotel managers. Regarding the quality of the information collected, telephone surveys provide a greater sense of anonymity, which usually results in increased sincerity. During telephone surveys the interviewer has less influence, allowing for the possibility of detecting errors and eliminating contamination between questions. These advantages undoubtedly reduce the bias of respondents. Díaz de Rada (2012) notes that, among the limitations of telephone surveys, questions must be clearer than in personal interviews, as this influences the quality of the answers; the interviewer can answer the questions raised from the questionnaire at the moment of the interview. This aspect can be considered a relative advantage, as respondents can bias the questions, by increasing the influence of the interviewer on the response and by decreasing the quality of the information collected. To avoid these limitations, the questionnaire was pilot tested at three-, four-, and five-star hotels with several senior managers, and academics from the hotel sector. Specific feedback was received on the clarity, comprehensiveness, and appropriateness of the scales. Minor edits and revisions were made to the questionnaire based on the recommendations received. When interviewing the respondents, no questions about the questionnaire were raised. The senior hotel managers who participated in the pilot questionnaire were not included in the sample. Thus, the target population consisted of 97 senior hotel managers. The telephone interviews led to a high response rate of $95 \%$, yielding a final sample size of 92 hotels operating in the province of Seville. Table 1 provides information about the respondents' demographics and the attributes of the participating hotels.

\subsection{Data analysis}

The research hypotheses were tested using Partial Least Squares (PLS), a variance-based structural modeling technique. PLS is a set of least squares algorithms that applies both principal component and canonical correlation analyses (Henseler et al., 2009). There are many justifications for using PLS in the present research: the sample of hotels used is small ( $n=92)$ and, following Reinartz et al. (2009), PLS should be applied when the sample size is under 250 observations; the research model is complex with respect to the variables (first- and high-order constructs) and the causal relationships (direct and indirect effects); and PLS provides robust estimations of non-normal distribution data (Ringle et al., 2012). SmartPLS v3.2.1 software was used to estimate the results of the model (Ringle et al., 2005). The intangible resources variable of a company was defined as a high-order construct (HOC) based on the low-order constructs (LOCs) of organizational, technical, marketing, and reputational resources. The researchers followed a twostep approach to operationalize the HOC (Henseler and Chin, 2010; Ringle et al., 2012). In the first stage, the repeated indicators focus provided the latent variable scores for the LOCs to be used as manifest variables to define the HOC of intangible resources. In the second stage, the researchers evaluated the structural model.

\section{Results}

The estimate of the structural equations model was evaluated in two stages: evaluation of the measurement model (outer model) and evaluation of the structural model (inner model).

\subsection{Measurement models}

Measurement models for reflective constructs were evaluated based on internal consistency via the composite reliability construct, each item's convergent reliability via average variance extracted (AVE), discriminant validity tested by the Fornell-Larcker criterion (Hair et al., 2012; Henseler et al., 2009), and the heterotrait-monotrait ratio of correlations (HTMT) (Henseler et al., 2015). As shown in Table 2, study 
Table 2

Measurement Model Reflective Constructs.

\begin{tabular}{|c|c|c|c|c|}
\hline Constructs & Items & Composite reliability & Item reliability & AVE \\
\hline \multirow[t]{5}{*}{ Competitive rivalry } & Physical characteristics & 0.852 & 0.703 & 0.573 \\
\hline & Service characteristics & & 0.846 & \\
\hline & Promotional strategies & & 0.798 & \\
\hline & Access to distribution channels & & 0.725 & \\
\hline & Geographical location & & 0.673 & \\
\hline \multirow[t]{5}{*}{ Market Performance } & & 0.973 & & 0.931 \\
\hline & Sales volume & & 0.942 & \\
\hline & Sales growth & & 0.953 & \\
\hline & Market share & & 0.925 & \\
\hline & Growth Market share & & 0.931 & \\
\hline \multirow[t]{4}{*}{ Profitability } & & 0.980 & & 0.953 \\
\hline & Profit margin & & 0.957 & \\
\hline & RevPar & & 0.962 & \\
\hline & Net profit & & 0.943 & \\
\hline \multirow[t]{5}{*}{ Marketing Capabilities } & & 0.941 & & 0.747 \\
\hline & Market Knowledge & & 0.817 & \\
\hline & Control and access to distribution channels & & 0.818 & \\
\hline & Advantageous relationships with customers & & 0.904 & \\
\hline & Installed customer base & & 0.791 & \\
\hline \multirow[t]{4}{*}{ Technical Capabilities } & & 0.801 & & 0.754 \\
\hline & Technical resources & & 0.804 & \\
\hline & Hotel equipment & & 0.865 & \\
\hline & Location & & 0.724 & \\
\hline \multirow[t]{7}{*}{ Organisational capabilities } & & 0.967 & & 0.835 \\
\hline & Ability to attract creative employees & & 0.782 & \\
\hline & Organisational & & 0.812 & \\
\hline & Strategic planning & & 0.818 & \\
\hline & Efficient organizational structure & & 0.890 & \\
\hline & Coordination & & 0.850 & \\
\hline & Employee skills and know-how & & 0.905 & \\
\hline \multirow[t]{5}{*}{ Reputational capabilities } & & 0.936 & & 0.687 \\
\hline & Environmental CSR & & 0.837 & \\
\hline & Promote women on boards & & 0.873 & \\
\hline & Improve the socioeconomic situation in the area it operates in & & 0.854 & \\
\hline & Improve social integration of vulnerable groups & & 0.808 & \\
\hline \multirow[t]{2}{*}{ Innovation differentiation } & $\mathrm{R} \& \mathrm{D}$ in product development & 0.862 & 0.889 & 0.758 \\
\hline & $\mathrm{R} \& \mathrm{D}$ in process innovations & & 0.874 & \\
\hline \multirow[t]{2}{*}{ Marketing differentiation } & Innovation in marketing techniques & 0.984 & 0.897 & 0.961 \\
\hline & Focus on Quality service for a chosen target market & & 0.897 & \\
\hline \multirow[t]{2}{*}{ Low Cost } & Automation of production process & 0.915 & 0.857 & 0.894 \\
\hline & Cost reduction & & 0.954 & \\
\hline
\end{tabular}

results show the measurement models meet all requirements. All reflective constructs in Table 2 present internally consistent reliability, with composite reliability measurements above 0.7 . All individual reflective items were reliable, with standardized loadings above 0.7. All constructs showed convergent validity, with AVE measures above 0.5.

As presented in Table 3, all variables meet discriminant validity requirements according to the Fornell-Larcker criterion. For satisfactory discriminant validity, the diagonal items should exceed the square correlations with any other construct (Barclay et al., 1995). Using HTMT as a criterion for validity, HTMT values close to 1 indicate a lack of discriminant validity (Henseler et al., 2015). All latent variables except profitability and market performance clearly meet the HTMT criterion. However, the HTMT between the profitability and market performance constructs is 0.90 , and, as these variables represent two dimensions of firm performance, this may indicate that these constructs could be synthesized as a HOC. In this research, however, the two constructs were retained, as HTMT confidence intervals with bootstrapping applied to test the hypothesis $\left(\mathrm{H}_{0}\right.$ : HTMT $\left.<1\right)$ do not contain a value of 1 , indicating discriminant validity.

When evaluating the formative measurement models, detected and weighted analyses are required in the presence of any multi-collinearity between items (Henseler et al., 2009). In Table 4, the variance inflation
Table 3

Measurement Model. Discriminant and HTMT Validity.

\begin{tabular}{|c|c|c|c|c|c|}
\hline & \multicolumn{3}{|c|}{$\begin{array}{l}\text { Fornell-Larcker discriminant } \\
\text { validity }\end{array}$} & \multicolumn{2}{|c|}{ HTMT validity } \\
\hline & 1 & 2 & 3 & 1 & 2 \\
\hline $\begin{array}{l}\text { 1. Rivalry } \\
\text { Competitive }\end{array}$ & 0.755 & & & & \\
\hline \multirow[t]{2}{*}{$\begin{array}{l}\text { 2. Market } \\
\text { Performance }\end{array}$} & 0.507 & 0.957 & & 0.635 & \\
\hline & & & & $\begin{array}{l}\text { C.I. }(0.521 \text {, } \\
0.783)\end{array}$ & \\
\hline 3. Profitability & 0.614 & 0.931 & 0.977 & $\begin{array}{l}0.683 \\
\text { C.I. }(0.621 \text {, } \\
0.735)\end{array}$ & $\begin{array}{l}0.90 \\
\text { C.I. }(0.858 \text {, } \\
0.932)\end{array}$ \\
\hline
\end{tabular}

Note: Diagonal items are AVE-Squared. Non-diagonal items are correlations between constructs.

factor (VIF) values for the manifest variables that compose the company assets' second-order formative construct are observed to be below 5 (Hair et al., 2011). The weights indicate the extent each dimension contributes to the construct (Henseler et al., 2009). According to Table 3, marketing capabilities contribute the most to firm assets, 
Table 4

Formative Measurement Model.

\begin{tabular}{|c|c|c|c|}
\hline Firm assets & Weights/ outer load & VIF & t-statistic \\
\hline Organisational & $\begin{array}{l}0.144^{12 \times k} \\
(0.752)\end{array}$ & 2.83 & 2.01 \\
\hline Marketing & $\begin{array}{l}0.156^{\text {thkx }} \\
(0.953)\end{array}$ & 4.09 & 3.65 \\
\hline Technical & $\begin{array}{l}0.235^{\text {*k }} \\
(0.872)\end{array}$ & 3.79 & 2.65 \\
\hline Reputational & $\begin{array}{l}0.567^{\text {thek }} \\
(0.857)\end{array}$ & 3.94 & 3.14 \\
\hline
\end{tabular}

$* * \mathrm{p}<0.05$

$* * *$ denotes $\mathrm{p}<0.01$.

followed by reputational, technical, and organizational capabilities, in that order.

\subsection{Structural model}

The estimated model is composed of reflective and formative constructs. Thus, the traditional PLS algorithm was applied to estimate path relationships (Dijkstra and Henseler, 2015) instead of using consistent PLS. The results of the estimated model (Fig. 1) are presented in Tables 5 and 6 . Table 5 shows the $\mathrm{R}^{2}$ of the endogenous variables and the direct paths observed from strategy, industry forces, and firm assets to firm performance (profitability and market performance), and the direct effect of market performance on profitability (Fig. 2).

Table 6 presents the mediating effects observed in the research model. Bootstrapping (5000 subsamples) provides the t-values to test the statistical significance of the primary direct and mediating effects in the research model. The model also appears to have adequate predictive power according to the predictive relevance $Q^{2}$ test of the endogenous reflective constructs-market performance and profitability-and the $\mathrm{Q}^{2}$ effect size calculated for the exogenous constructs (Table 6). The cross-validated redundancy measure is highly recommended for examining the research model's predictive relevance (Hair et al., 2012). Study results presented in Table 6 show that firm assets have great predictive power for market performance, while the other exogenous constructs have a moderate predicted effect on the endogenous variable. All the exogenous variables have a large predictive effect on the profitability variable.

The standardized root mean square residual (SRMR), defined as the difference between the observed correlation and the predicted correlation, is a PLS-SEM goodness of fit measure to detect model misspecification (Henseler et al., 2015). A value below 0.10, or, more conservatively, 0.08 (Hu and Bentler, 1995) is considered a good fit. The value of this composite factor model's SRMR is 0.097 , indicating that the model specification is within the satisfactory threshold. As
Table 6

Cross-validated redundancy measures and $\mathrm{q}^{2}$ effect size.

\begin{tabular}{lllll}
\hline Market Performance & & & Profitability \\
\cline { 5 - 6 } $\mathrm{Q}^{2}=0.586$ & & & $\mathrm{Q}^{2}=0.890$ & \\
\cline { 5 - 6 } Exogenous construct & $\mathrm{q}^{2}$ & & Exogenous construct & $\mathrm{q}^{2}$ \\
Firm assets & 0.444 & & Firm assets & 0.9182 \\
Marketing & 0.1719 & & Marketing & 0.9232 \\
Innovation & 0.1643 & & Innovation & 0.9091 \\
Low cost & 0.1670 & & Low cost & 0.9273 \\
Industry Forces & 0.1393 & & Industry Forces & 0.7272 \\
\hline
\end{tabular}

shown in Table 7, the mediating effects hypothesis was tested following the Preacher and Hayes (2008) approach.

As presented in Tables 5 and 7, study results suggest that competitive rivalry has no significant direct influence on profitability or market performance. Based on this finding, H1a is rejected. Market performance does not mediate the relationship between competitive rivalry and profitability. Based on this study, H1b is rejected.

Firm assets have a significant direct positive effect on performance, but not on profitability. According to this finding, H2a is partially confirmed. The indirect effect of firm assets on market performance is observed through innovation differentiation. Indirect effects are also observed between firm assets and profitability through marketing and innovation differentiation. Thus, H2b is partially confirmed.

Strategies based on marketing differentiation and innovation differentiation have a direct positive effect on market performance, while hotel managers perceive that the low-cost strategy has a significant negative effect on market performance. Additionally, these strategies do not appear to have a direct significant influence on profitability. Based on this finding, H3a is partially confirmed. No mediating effect of competitive rivalry is observed between these strategies and market performance. However, marketing differentiation is observed to have a mediating effect on profitability through competitive rivalry. According to this finding, H3b is partially confirmed.

\section{Discussion and conclusions}

This study aimed to investigate the competitive success factors for hotel companies and examine the link between business strategy and performance. Using a structural equations model to identify and explain the complex relationships that develop within a company, the present study covers an important gap in the literature. The study results provide new insights from the hotel industry in Spain on the link between business strategy and firm performance. It is evident that both industryand firm-level factors are significant determinants of performance.

Table 5

Structural Model Results: Direct Effects.

\begin{tabular}{|c|c|c|c|c|c|c|}
\hline & \multirow{2}{*}{$\begin{array}{l}\text { Industry Forces } \\
\text { Competitive Rivalry } \\
\mathrm{R}^{2}=0.604\end{array}$} & \multicolumn{2}{|l|}{ Performance } & \multicolumn{3}{|l|}{ Strategy } \\
\hline & & $\begin{array}{l}\text { Market Performance } \\
\mathrm{R}^{2}=0.585\end{array}$ & $\begin{array}{l}\text { Profitability } \\
\mathrm{R}^{2}=0.831\end{array}$ & $\begin{array}{l}\text { Innovation } \\
\mathrm{R}^{2}=0.268\end{array}$ & $\begin{array}{l}\text { Low cost } \\
\mathrm{R}^{2}=0.213\end{array}$ & $\begin{array}{l}\text { Marketing } \\
\mathrm{R}^{2}=0.436\end{array}$ \\
\hline Competitive Rivalry & & $0.03(0.240)$ & $0.123(1.301)$ & & & \\
\hline \multicolumn{7}{|l|}{ Market Performance } \\
\hline Profitability & & $0.812^{* * *}(16.26)$ & & & & \\
\hline Firm assets & & $0.522^{* * *}(5.763)$ & $-0.065(0.904)$ & $0.517 * * *(6.309)$ & $-0.033(0.235)$ & $0.66^{* * *}(10.436)$ \\
\hline innovation & $0.335^{* * *(2.976)}$ & $0.221 * * *(2.486)$ & $0.031(0.423)$ & & & \\
\hline Low cost & $0.043(0.671)$ & $-0.13^{* *}(1.988)$ & $-0.043(0.881)$ & & & \\
\hline marketing & $0.475^{* * *}(3.415)$ & $0.142^{* * *}(2.01)$ & $0.067(0.698)$ & & & \\
\hline Size & $0.475^{* * *(3.415)}$ & $0.125^{* *}(1.907)$ & $0.107 * * *(11.642)$ & & & \\
\hline
\end{tabular}

Note: Two-tail test*** denotes $\mathrm{p}<0.01$; ${ }^{* *} \mathrm{p}<0.05$; ${ }^{*} \mathrm{p}<0.10$. 


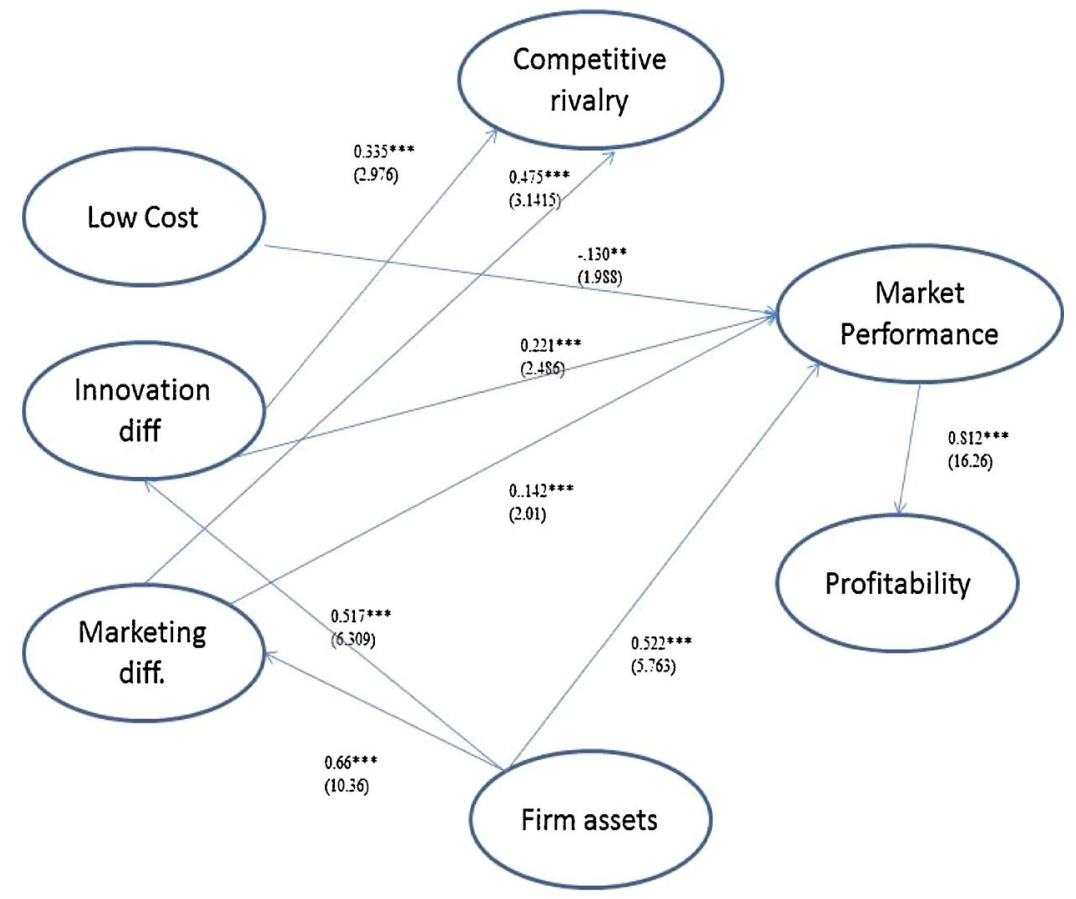

Fig. 2. Research Model: Main direct Effects. Note: Only significance paths are presented.

Table 7

Mediating effects.

\begin{tabular}{|c|c|c|c|}
\hline & \multirow[b]{2}{*}{ Indirect effect } & \multicolumn{2}{|c|}{ Bias corrected bootstrap $95 \%$ Confidence Interval } \\
\hline & & Lower & Upper \\
\hline Firm assets $\rightarrow$ Marketing Diff $\rightarrow$ Market Performance & 0.09372 & -0.1743 & 0.3060 \\
\hline Firm assets $\rightarrow$ Innovation Diff $\rightarrow$ Market Performance & 0.1091 & 0.0737 & 0.3119 \\
\hline Firm assets $\rightarrow$ Low cost $\rightarrow$ Market Performance & -0.0043 & -0.0395 & 0.0460 \\
\hline $\begin{array}{l}\text { Firm assets } \rightarrow \text { Marketing Diff } \rightarrow \text { Profitability }+ \text { Firm assets } \rightarrow \text { Marketing Diff } \rightarrow \text { Market Performance } \rightarrow \\
\quad \text { Profitability }\end{array}$ & 0.16982 & 0.1121 & 0.3379 \\
\hline $\begin{array}{l}\text { Firm assets } \rightarrow \text { Innovation Diff } \rightarrow \text { Profitability }+ \text { Firm assets } \rightarrow \text { Innovation Diff } \rightarrow \text { Market Performance } \rightarrow \\
\quad \text { Profitability }\end{array}$ & 0.1185 & 0.077 & 0.3032 \\
\hline Firm assets $\rightarrow$ Low cost $\rightarrow$ Profitability + Firm assets $\rightarrow$ Low cost $\rightarrow$ Market Performance $\rightarrow$ Profitability & 0.0046 & -0.1862 & 0.0987 \\
\hline Marketing Diff $\rightarrow$ Competitive Rivalry $\rightarrow$ Market Performance & 0.0142 & -0.1456 & 0.1009 \\
\hline Innovation Diff $\rightarrow$ Competitive Rivalry $\rightarrow$ Market Performance & 0.0100 & -0.1871 & 0.1175 \\
\hline Low cost Diff $\rightarrow$ Competitive Rivalry $\rightarrow$ Market Performance & 0.0013 & -0.2131 & 0.0962 \\
\hline $\begin{array}{l}\text { Marketing Diff } \rightarrow \text { Competitive Rivalry } \rightarrow \text { Profitability }+ \text { Marketing Diff } \rightarrow \text { Competitive Rivalry } \rightarrow \text { Market } \\
\text { performance } \rightarrow \text { Profitability }\end{array}$ & 0.0686 & 0.0499 & 0.15174 \\
\hline $\begin{array}{l}\text { Innovation Diff } \rightarrow \text { Competitive Rivalry } \rightarrow \text { Profitability }+ \text { Innovation Diff } \rightarrow \text { Competitive Rivalry } \rightarrow \text { Market } \\
\text { performance } \rightarrow \text { Profitability }\end{array}$ & 0.0424 & -0.0873 & 0.1874 \\
\hline $\begin{array}{l}\text { Low cost } \rightarrow \text { Competitive Rivalry } \rightarrow \text { Profitability }+ \text { Low cost } \rightarrow \text { Competitive Rivalry } \rightarrow \text { Market performance } \rightarrow \\
\quad \text { Profitability }\end{array}$ & 0.0063 & -0.1142 & 0.0951 \\
\hline Competitive Rivalry $\rightarrow$ Market Performance $\rightarrow$ Profitability & 0.0246 & -0.2243 & 0.1601 \\
\hline
\end{tabular}

Note: Bootstrapping based on $\mathrm{n}=5000$ subsamples.

\subsection{Firm assets and performance (market performance, profitability)}

A direct, positive, and significant relationship can be observed between firm assets and market performance, but not profitability (Table 5). Factors such as capabilities and organizational, marketing, technical, and reputational resources have a direct impact on sales growth. In other words, specific resources in the hotel sector, such as brand image; organizational structure; employee know-how; and technological resources, such as centralized booking systems, revenue management, and information systems, help increase sales volume. However, no direct influence of firm assets on profitability is observed. The lack of a direct influence of firm assets on profitability was demonstrated in several previous studies (Cool and Schendel, 1988; Lawless et al., 1989). Undoubtedly, firm assets contribute to an increase in sales, since they generate a positive image of the company. In a postcrisis period, as analyzed in the study, a firm is not able to increase its contribution margin (i.e., price-variable cost) and the direct effect of firm assets on profitability is observed, although it is not statistically significant. However, a statistically significant relationship between firm assets and profitability is observed through market performance in the research model, given the relationship between the two firm-performance dimensions. In a different scenario, such as one characterized by a high demand where it is normal to raise prices, the direct relationships between firm assets and profit could perhaps have been observed.

Firm assets indirectly affect market performance via the innovation differentiation strategy (Table 7). Process innovations in the hotel sector are predominantly comprised of the following, according to ITH (2008): the rapid growth in the use of the internet as a marketing and sales mechanism, demand transformation characterized by better-informed customers, seasonally-adjusted demand, shortened lengths of stay, and lower transportation costs (i.e., low-cost strategies). $80 \%$ of 
innovative hotels have focused on the introduction of new methods of sales or distribution, which has had a positive effect on sales and, therefore, has led to a positive effect on market performance (ITH, 2008). However, firm assets have an indirect effect on profitability via marketing and innovation differentiation strategies, but not via lowcost ones (Table 7). This result is understandable, as the marginal cost of the hotel product is very low and, consequently, the exploitation cost has a little influence on profitability. It should be noted that hotel operating costs are essentially the room service cost and the wage cost (AECA, 2015; Amat and Campa, 2011). The room service cost is practically non-existent, and the salary cost is constrained to regulation, meaning the manager cannot fully control it. Consequently, a senior hotel manager needs to focus more on differentiation strategies than cost strategies (Amat and Campa, 2011; Martín and Moreno, 2014). As mentioned in the introduction, this type of service involves the customer in the service delivery process, meaning that the customer can modify the cost (AECA, 2015). However, marketing and innovation differentiation are based on offering a quality service to an elite market demographic that is not very price sensitive, resulting in higher profits.

\subsection{Strategic actions and performance (market performance, profitability)}

Marketing and innovation-differentiation strategies have a direct positive effect on market performance. However, hotel managers perceive that the low-cost strategy has a direct and negative effect on market performance if the low-cost strategy is aimed at reducing prices to increase the market share (Table 5). The idea behind this assumption is that the customers of three- to five-star hotels might associate a decreased price with a reduction in the quality of the services offered and choose to book accommodation elsewhere (Cool and Schendel, 1988; Lawless et al., 1989; Martín Samper, 2004).

Marketing differentiation is observed to have only an indirect influence on profitability via competitive rivalry (Table 7). This is logical, considering that this strategy is based on the use of competitive rivalry to create differentiation by improving a firm's strategic position over its competitors, targeting the less cost-sensitive market segments that generate greater visible profits through indicators such as RevPar (Borrego, 2011; Rosa Pérez and Velasco Gimeno, 2013). Except for the above-mentioned relationship, no significant relationships are observed between the various strategies and firm performance via industry forces (Table 7). These non-significant relationships are understandable in the midscale-to-luxury categories of the hotel sector, where competition is limited due to a high concentration of three- to five-star hotels belonging to the same chain in the analyzed context. Consequently, this is linked to low rivalry and a reduction in competition, giving this factor little influence on firm performance. A prior study analyzing the competitive structure of midscale-to-luxury category hotels in Seville observed that the primary companies shared information about the prices and features of their services to arrive at an implicit agreement about acceptable price ranges (Martín Samper, 2004). Being one of the first studies in the field, these findings and discussions provide specific theoretical and managerial implications.

\subsection{Theoretical implications}

The findings of this study offered several clear theoretical implications relating to strategy and performance research in the strategic management field. First, the study results suggest that the firm market positioning approach (Porter, 1980) and the RBV (Barney, 1991) complement each other. In fact, as observed in the research model, the strategic actions are conditioned to their firm assets. Thus, the influence of the firm assets on firm market positioning is through strategic actions.

Firm assets directly influence market performance. In fact, a hotel's intangible resources, such as its organizational culture and structure, management style, staff training, reputation, and brand image, have a positive effect on sales and, consequently, on market performance. Firm assets also influence market performance via the mediating effect of the innovation differentiation strategy, producing an increase in sales. This differentiation strategy, especially relating to innovation differentiation in processes such as the application of yield management, the Uniform System of Accounts for the Lodging Industry, check-in and check-out processes, and service quality (ITH, 2008; Thinktur, 2016) directly influence performance. According to the opinions of the senior hotel managers who took part in the study, bookings, marketing and sales, and quality (i.e., management systems) are the business areas where innovations occur with greater frequency, which corroborates the hotel sector's tendency to prioritize innovation in processes over all other types of innovation, as stated by the Spanish Hotel Technological Institute (ITH, 2008; Hjalager, 2010; Thinktur, 2016).

Second, the research findings show that the firm assets, such as organizational structure, management style, management models, staff training, reputation, brand image, and technological resources (Eisenhardt and Martin, 2000), have no direct influence on profitability. However, they seem to have an indirect effect via marketing and innovation differentiation strategies, but not via low-cost strategies. Sometimes innovation and marketing strategies can be aimed at offering better quality service, and even though this situation might cause prices at the hotel to rise, it may not necessarily affect the customer's purchase decision, especially for demographics that are not price-sensitive. As the hotel sector is highly seasonal, it is forced to adapt demand to its capacity through price variations. Thus, more consumers may be aware of lower prices and choose to opt for higherquality offers. Consequently, hotel companies positioned in a differentiated customer sector should offer the incentive of large discounts during low-demand periods. Hotel companies with lower rates increase their prices during periods of high demand, diluting their strategic positioning in the market. Moreover, inventory management tools, such as revenue management, are a cause of price variations under those circumstances, which might confuse inexperienced customers about a company's position (Martin and Moreno, 2014).

Finally, the research findings reveal that the simultaneous application of low-cost and differentiation strategies does not lead to profitability, as professed by Porter (1980). Additionally, the simultaneous application of positioning and RBV strategies does not lead to profitability. Successfully applying these strategies so they complement each other depends on the conditions hotels operate under. Competitive intensity is a significant element of competition (Porter, 1980). The research findings suggest that the RBV is more applicable in higher intensity environments, and in areas such as innovation management, brand management, and efficiency management.

\subsection{Managerial implications}

The study results imply that, while resources and strategies directly influence market performance, they have no direct influence on profitability. Logically, however, market performance has a positive influence on profitability in the hotel sector, which is characterized by seasonality, intangibility, and perishability. As the focus of the hotel industry is achieving higher occupancy rates, hotel managers should know that increasing profitability is done by increasing the occupancy rate or increasing sales. This can also be observed in the indirect effect of resources on profitability via certain strategies in the proposed model. It is logical for managers to place greater importance on differentiation in innovation, with the aim of boosting market performance growth and, consequently, profitability based on the use of technological advances in distribution channels. It is also essential to consider the specific characteristics of the firm under study, where differentiation is closely linked to price. However, as the hotel industry is subject to large variations in demand, it is forced to modify tariffs and create packages to entice consumers. This can confuse the public, making it difficult to position the service clearly in the market. 
The hotel industry is undergoing a major competitive and technological transformation that forces them to adapt to new scenarios (Talón-Ballestero et al., 2014). Although some managerial decisions and actions are made at corporate or regional levels for hotels belonging to a chain, the new, competitive environment encourages managers not only to favor the implementation of the suggested innovations at the corporate level, but also to promote an innovative culture at the hotel level by informing and training the staff regarding product and process innovations, thus promoting innovations adapted to the changes facing the sector. Managers from non-chain hotels must form alliances in the hotel sector to implement innovations that allow hotels to operate in the market more efficiently. Managers should also promote process and product innovations among their staff, encouraging efficiency and increasing the hotel's profitability and market performance.

Price variations might lead some consumers to misunderstand the hotel's relationship with price related to quality. The hotel departments responsible for marketing, communication, and pricing decisions should develop differentiated services, such as weekend offers, Last Room Available (LRA), Best Rate Guarantee (BRG), and information campaigns to prevent such misunderstandings. Thus, the product offered would be differentiated with variable other than the price to justify for the hotel's decisions to the customer. This issue should be taken into consideration when applying a revenue management system (Martín-Sámper and Moreno-Rojas, 2014).

\section{Limitations and future research}

As with any research, this study has several limitations. First, the data were collected from urban, midrange, and luxury hotels in a significant heritage destination in Spain. New lines of research might further test the proposed model in the hotel industry in other destinations. Second, the data were collected via telephone surveys. Future studies may collect data via semi-structured interviews. It would also be interesting to conduct a multi-group analysis analyzing the relationships between different hotel types (e.g., resort versus urban) and exploring possible moderating relationships that are not included in the model, such as the hotel manager's gender or the hotel's ownership. The inclusion of moderating variables may also help researchers understand how decisions are made in midscale and luxury hotels not only on the basis of resources and strategies but also of position compared to competitors. Such a study could also examine how the socio-demographic features of hotel managers (such as gender, age, education, or years of experience), a hotel's inclusion in a chain, and the hotel's management style influence competitive strategies and performance.

\section{Appendix A. Questionnaire: Competitive Factors in the Hotel Industry}

Irrespective of whether you have used them or not, how important are the following resources in underpinning your establishment's competitiveness and success? (1 = Minimum to 7 = Maximum):

Staff policy designed to hire, train and retain the company's human an creative talent.

Improved share organizational values, benefits, attitudes and behaviours.

Company organizational structure (ways in which functions, hierarchy and fluidity of relationships are organized.

Departmental coordination and communication between different levels of the hierarchy.

Existence of a strategic plan.

Current state of the hotel (infrastructure, equipment, etc.).

Establishment location.

Skills, knowledge, creativity and know-how of hotel employees.

Market knowledge.
Control and access to distribution channels.

Install customer base.

Use of technological resources (electronic sales, use of central reserve system, intranet, etc.).

Action designed to improve environmental management.

Action designed to promote the incorporation of women into management positions.

Action designed to improve the socio-economic situation of the community where your establishment is located.

Action for the social integration of disadvantaged groups (disabled, immigrants, etc.).

Control and access to distribution channels.

Please, indicate the position of your hotel in relation to the competitors in the last three years $(1=$ very low with respect to the mean and 7 = very high with respect to the mean) according to the following items:

Total sales volumes.

Growth in total sales volumes.

Market share.

Growth in market share.

Net profit.

Revpar (total revenue from rooms/number of rooms available).

Please, indicate the degree to which you use the following strategies ( 1 = Much less than our competitors to $7=$ Much more than our competitors):

Differentiation based on delivering a qualitative service to a select market.

Low cost production to offer an economic and accessible service to a wider market.

Modernization and automation of a production and commercialization process.

Innovations in Marketing, i.e, in the service is marketed.

product Innovation.

process Innovation (Yield management, Usually, management systems...).

How would you rate the strength with which your hotel uses the following factors to compete in the market $(1=$ Very weak to 7 = Very strong)?

Your hotel's physical characteristics.

Characteristics of the service delivered.

Promotional strategies.

Access to distribution channels and marketing networks.

Geographical location.

\section{References}

AECA, 2013. Marco Conceptual del turismo. Documento nº1 Asociación Española de Contabilidad y Auditoría., Madrid.

AECA, 2015. El sistema Uniforme de Cuentas para los Establecimientos Hoteleros. Documento $n^{\circ} 3$ Asociación Española de Contabilidad y Auditoría, Madrid.

Achrol, R.S., Stern, L.W., 1988. Environmental determinants of decision-making uncertainty in marketing channels. J. Market. Res. 25, 36-50.

Amat, O., Campa, F., 2011. Contabilidad, Control de Gestión y Finanzas de Hoteles. Profit Editorial, Barcelona.

Ambrosini, V., Bowman, C., 2009. What are dynamic capabilities and are they a useful construct in strategic management? Int. J. Manage. Rev. 11, 29-49.

Armanios, D.E., Eesley, C.E., Li, J., Eisenhardt, K.M., 2017. How entrepreneurs leverage institutional intermediaries in emerging economies to acquire public resources. Strateg. Manage. J. 38, 1373-1390.

Avci, U., Madanoglu, M., Okumus, F., 2011. Strategic orientation and performance of tourism firms: evidence from a developing country. Tour. Manage. 32, 147-157.

Backman, C.A., Verbeke, A., Schulz, R.A., 2017. The drivers of corporate climate change strategies and public policy. Bus. Soc. 56, 545-575.

Bain, J., 1959. Industrial Organization. John Wiley and Sons, New York.

Balkin, D.B., Gomez-Mejia, L.R., 1987. Toward a contingency theory of compensation strategy. Strateg. Manage. J. 8, 169-182.

Barclay, D.W., Higgins, C.A., Thompson, R., 1995. The partial least squares approach to causal modeling: personal computer adoption and use as illustration. Technol. Stud. 2, 285-309.

Barney, J., 1991. Firm resources and sustained competitive advantage. J. Manage. 17, 99-120. 
Barros, I., Hernangómez, J., Martin-Cruz, N., 2016. A theoretical model of strategic management of family firms: a dynamic capabilities approach. J. Fam. Bus. Strategy 7, 149-159.

Borrego, A.J., 2011. Administración y control de la actividad hotelera y de restauración a través del USALI (Uniform System of Account for the Lodging Industry) Análisis y Soluciones de Gestión. SLU, Sevilla.

Brenes, E.R., Camacho, A.R., Ciravegna, L., Pichardo, C.A., 2016. Strategy and innovation in emerging economies after the end of the commodity boom-Insights from Latin America. J. Bus. Res. 69, 4363-4367.

Bridoux, F., 2004. A Resource-based Approach to Performance and Competition: An Overview of the Connections Between Resources and Competition. avalaible at: https://www.uclouvain.be/cps/ucl/doc/iag/documents/WP_110_Bridoux.pdf (Accessed 20 February 2016).

Brooking, A., 1996. Intellectual Capital. International Thomson Business Press, London.

Chathoth, P.K., Olsen, M.D., 2007. The effect of environment risk, corporate strategy, and capital structure on firm performance: an empirical investigation of restaurant firms. Int. J. Hosp. Manage. 26, 502-516.

Claver-Cortés, E., Molina-Azorín, J.F., Pereira-Moliner, J., 2007. The impact of strategic behaviours on hotel performance. Int. J. Contemp. Hosp. Manage. 19, 6-20.

Conner, K.R., 1991. A historical comparison of resource-based theory and five schools of thought within industrial organization economics: do we have a new theory of the firm? J. Manage. 17, 121-154.

Cool, K., Schendel, D., 1988. Performance differences among strategic group members. Strateg. Manage. J. 9, 207-223.

Díaz de Rada, V.D., 2012. Ventajas e inconvenientes de la encuesta por Internet. Papers: Revista de Sociología 97 (1), 193-223.

Darcy, C., Hill, J., McCabe, T., McGovern, P., 2014. A consideration of organisational sustainability in the SME context: a resource-based view and composite model. Eur. J. Train. Dev. 38, 398-414.

Day, G.S., Wensley, R., 1988. Assessing advantage: a framework for diagnosing competitive superiority. J. Market. 52, 1-20.

Dijkstra, T.K., Henseler, J., 2015. Consistent partial least squares path modeling. MIS Q 39, 297-316.

Dikova, D., Witteloostuijn, A.V., Parker, S., 2017. Capability, environment and internationalization fit, and financial and marketing performance of MNEs' foreign subsidiaries: an abductive contingency approach. Cross Cult. Strateg. Manage. 24, 405-435.

Dodd, M.D., 2016. Intangible resource management: social capital theory development for public relations. J. Commun. Manage. 20, 289-311.

Durand, R., Grant, R.M., Madsen, T.L., 2017. The expanding domain of strategic management research and the quest for integration. Strateg. Manage. J. 38, 4-16.

Eisenhardt, K.M., Martin, J.A., 2000. Dynamic capabilities: what are they? Strateg. Manage. J. 21, 1105-1121.

Fernández-Olmos, M., Ramírez-Alesón, M., 2017. How Internal and External Factors Influence the Dynamics of SME Technology Collaboration Networks over Time. Technovation.

Furrer, O., Thomas, H., Goussevskaia, A., 2008. The structure and evolution of the strategic management field: a content analysis of 26 years of strategic management research. Int. J. Manage. Rev. 10, 1-23.

Galbreath, J., Galvin, P., 2006. Accounting for Performance Variation: How Important Are Intangible Resources? Working Paper 60. Graduate School of Business, Curtin University of Technology, Perth, Western Australia.

Garrigós-Simón, F.J., Marqués, D.P., Narangajavana, Y., 2005. Competitive strategies and performance in Spanish hospitality firms. Int. J. Contemp. Hosp. Manage. 17, 22-38.

Grant, R.M., 2016. Contemporary Strategy Analysis, ninth ed. John Wiley \& Sons Ltd., West Sussex.

Greco, M., Cricelli, L., Grimaldi, M., 2013. A strategic management framework of tangible and intangible assets. Eur. Manage. J. 31, 55-66.

Hair, J.F., Ringle, C.M., Sarstedt, M., 2011. PLS-SEM: indeed a silver bullet. J. Market. Theory Pract. 19, 139-152.

Hair, J.F., Sarstedt, M., Ringle, C.M., Mena, J.A., 2012. An assessment of the use of partial least squares structural equation modeling in marketing research. J. Acad. Market. Sci. 40, 414-433.

Hamdan, A.L., 2017. Porter's Strategies in Healthcare, Strategic Thinking in a Hospital Setting. Springer International Publishing, Cham, pp. 9-15.

Hannan, M.T., Freeman, J., 1977. The population ecology of organizations. Am. J. Sociol. 929-964.

Henseler, J., Chin, W.W., 2010. A comparison of approaches for the analysis of interaction effects between latent variables using partial least squares path modeling. Struct. Equ. Model. 17, 82-109.

Henseler, J., Ringle, C.M., Sinkovics, R.R., 2009. The use of partial least squares path modeling in international marketing. New Chall. to Int. Market. 277-319.

Henseler, J., Ringle, C.M., Sarstedt, M., 2015. A new criterion for assessing discriminant validity in variance-based structural equation modeling. J. Acad. Market. Sci. 43 115-135.

Hitt, M.A., Carnes, C.M., Xu, K., 2016. A current view of resource based theory in operations management: a response to Bromiley and Rau. J. Oper. Manage. 41 , 107-109.

Hjalager, A., 2010. A review innovation research in tourism. Tour. Manage. 31, 1-12.

Hoopes, D.G., Madsen, T.L., Walker, G., 2003. Guest editors' introduction to the specia issue: why is there a resource-based view? Toward a theory of competitive heterogeneity. Strateg. Manage. J. 24, 889-902.

Hoskisson, R.E., Eden, L., Lau, C.M., Wright, M., 2000. Strategy in emerging economies. Acad. Manage. J. 43, 249-267.

Hoskisson, R.E., Wei, S.H.I., Xiwei, Y.I., Jing, J.I.N., 2013. The evolution and strategic positioning of private equity firms. Acad. Manage. Perspect. 27, 22-38.
Hu, L.-T., Bentler, P.M., 1995. Evaluating model fit. In: Hoyle, R.H. (Ed.), Structura Equation Modeling: Concepts, Issues, and Applications. Sage, Thousand Oaks, California.

ITH, 2008. Innovación en el sector hotelero. Fundación Cotec para la Innovación Tecnológica, Madrid.

Kellermanns, F., Walter, J., Crook, T.R., Kemmerer, B., Narayanan, V., 2016. The resource-based view in entrepreneurship: a content-analytical comparison of researchers' and entrepreneurs' views. J. Small Bus. Manage. 54, 26-48.

Koseoglu, M.A., Topaloglu, C., Parnell, J.A., Lester, D.L., 2013. Linkages among business strategy, uncertainty and performance in the hospitality industry: evidence from an emerging economy. Int. J. Hosp. Manage. 34, 81-91.

Koseoglu, M.A., Ross, G., Okumus, F., 2016. Competitive intelligence practices in hotels Int. J. Hosp. Manage. 53, 161-172.

Kraaijenbrink, J., Spender, J.C., Groen, A.J., 2010. The resource-based view: a review and assessment of its critiques. J. Manage. 36 (1), 349-372.

Kull, A.J., Mena, J.A., Korschun, D., 2016. A resource-based view of stakeholder marketing. J. Bus. Res. 69, 5553-5560.

Lado, A.A., Boyd, N.G., Wright, P., 1992. A competency-based model of sustainable competitive advantage: toward a conceptual integration. J. Manage. 18, 77-91.

Lam, C., Ho, G.K.S., Law, R., 2015. How can Asian hotel companies remain internationally competitive? Int. J. Contemp. Hosp. Manage. 27, 827-852.

Law, V.T., Tavitiyaman, P., Zhang, H.Q., 2015. An analysis of industry forces, strategic implementation, and performance: evidence from state-owned hotels in China. J. of China Tour. Res. 11 (3), 315-336.

Lawless, M.W., Bergh, D.D., Wilsted, W.D., 1989. Performance variations among strategic group members: an examination of individual firm capability. J. Manage. 15, 649-661.

Leonard-Barton, D., 1995. Wellsprings of Knowledge: Building and Sustaining the Sources of Innovation. Harvard Business School Press, Boston, MA.

Leonidou, L.C., Leonidou, C.N., Fotiadis, T.A., Zeriti, A., 2013. Resources and capabilities as drivers of hotel environmental marketing strategy: implications for competitive advantage and performance. Tour. Manage. 35, 94-110.

Lin, Y., Wu, L.Y., 2014. Exploring the role of dynamic capabilities in firm performance under the resource-based view framework. J. Bus. Res. 67 (3), 407-413.

Lo, Y., 2012. Back to hotel strategic management 101: an examination of hotels' implementation of Porter's generic strategy in China. J. Int. Manage. Stud. 7, 56-69.

Lockett, A., Wild, A., 2014. Bringing history (back) into the resource-based view. Bus. Hist. 56, 372-390.

Mahoney, J.T., Pandian, J.R., 1992. The resource-based view within the conversation of strategic management. Strateg. Manage. J. 13, 363-380.

Marco-Lajara, B., Zaragoza-Sáez, P.d.C., Claver-Cortés, E., Úbeda-García, M., 2016. Hote performance and knowledge sources in Spanish tourism districts. Curr. Issues Tour. $1-26$.

Martín Samper, R.C., 2004. Determinación de Precio en la Empresa Hotelera: un Estudio de Caso, Facultad de Ciencias Económicas y Empresariales. Universidad de Sevilla.

Martín-Sámper, C., Moreno-Rojas, J., 2014. Una aproximación holística a la determinación y gestión de precios en las compañías hoteleras. Innovar 24 (51), 45-60.

Martin, R.C., Moreno, J., 2014. Una aproximación holística a la determinación y gestión de precios en las compañías hoteleras. Revista Innovar 24, 45-59.

Mason, E., 1949. The current state of the monopoly problem in the U.S. Harv. Law Rev. $62,1265-1285$.

McAdam, R., Miller, K., McSorley, C., 2016. Towards a contingency theory perspective of quality management in enabling strategic alignment. Int. J. Prod. Econ. http://dx.doi. org/10.1016/j.ijpe.2016.07.003.

Miller, D., 1988. Relating porter's business strategies to environment and structure: analysis and performance implications. Acad. Manage. J. 31, 280-308.

Notta, O., Vlachvei, A., 2017. Competitive strategies and managers' perceptions in greek food manufacturing firms. In: Kavoura, A., Sakas, D.P., Tomaras, P. (Eds.), Strategic Innovative Marketing: 4th IC-SIM, Mykonos, Greece 2015. Springer International Publishing, Cham, pp. 245-251.

Paladino, A., Widing, R., Whitwell, G., 2015. Internal and external organisational orientations: comparing the resource based view and market orientation. Globa Perspectives in Marketing for the 21 st Century. Springer, Cham, pp. 338

Parnell, J.A., 2006. Generic strategies after two decades: a reconceptualization of competitive strategy. Manage. Dec. 44, 1139-1154.

Pereira-Moliner, J., Font, X., Tarí, J.J., Molina-Azorin, J.F., Lopez-Gamero, M.D., PertusaOrtega, E.M., 2015. The Holy Grail: environmental management, competitive advantage and business performance in the Spanish hotel industry. Int. J. Contemp. Hosp. Manage. 27, 714-738.

Phillips, P.A., 1999. Hotel performance and competitive advantage: a contingency approach. Int. J. Contemp. Hosp. Manage. 11, 359-365.

Porter, M.E., 1980. Competitive Strategy: Techniques for Analyzing Industries and Competitors. Free Press, New York.

Porter, M.E., 1985. Competitive Advantage: Creating and Sustaining Superior Performance. Free Press, New York.

Porter, M.E., 1991. Towards a dynamic theory of strategy. Strateg. Manage. J. 12, 95-117.

Preacher, K.J., Hayes, A.F., 2008. Asymptotic and resampling strategies for assessing and comparing indirect effects in multiple mediator models. Behav. Res. Methods 40, 879-891.

Ramanathan, R., Ramanathan, U., Zhang, Y., 2016. Linking operations, marketing and environmental capabilities and diversification to hotel performance: a data envelopment analysis approach. Int. J. Prod. Econ. 176, 111-122.

Reinartz, W., Haenlein, M., Henseler, J., 2009. An empirical comparison of the efficacy of covariance-based and variance-based SEM. Int J. Res. Market. 26, 332-344. 
Ringle, C., Wende, S., Will, A., 2005. SmartPLS 2.0 (M3) Beta. Hamburg, Germany. Ringle, C.M., Sarstedt, M., Straub, D., 2012. A Critical Look at the Use of PLS-SEM in MIS Quarterly.

Rosa Pérez, E., Velasco Gimeno, M., 2013. Indicadores de rentabilidad del sector hotelero. Índice 56, 10 .

Schroeder, R.G., Bates, K.A., Junttila, M.A., 2002. A resource-based view of manufacturing strategy and the relationship to manufacturing performance. Strateg. Manage. J. 23, 105-117.

Shirokova, G., Bogatyreva, K., Beliaeva, T., Puffer, S., 2016. Entrepreneurial orientation and firm performance in different environmental settings: contingency and configurational approaches. J. Small Bus. Enterp. Dev. 23, 703-727.

Spanos, Y.E., Lioukas, S., 2001. An examination into the causal logic of rent generation: contrasting Porter's competitive strategy framework and the resource-based perspective. Strateg. Manage. J. 22, 907-934.

Srivastava, R.K., Fahey, L., Christensen, H.K., 2001. The resource-based view and marketing: the role of market-based assets in gaining competitive advantage. J. Manage 27, 777-802.

Stead, J.G., Stead, W.E., 2016. Spiritual capabilities: keys to successful sustainable strategic management. In: Dhiman, S., Marques, J. (Eds.), Spirituality and Sustainability:
New Horizons and Exemplary Approaches. Springer International Publishing, Cham, pp. 89-103.

Talón-Ballestero, P., González-Serrano, L., Figueroa-Domecq, C., 2014. A model for evaluating revenue management implementation (MERMI) in the hotel industry. J. Revenue Pricing Manage. 13 (4), 309-321.

Teece, D.J., Pisano, G., Shuen, A., 1997. Dynamic capabilities and strategic management. Strateg. Manage. J. 18, 509-533.

Teece, D.J., Peteraf, M., Leih, S., 2016. Dynamic capabilities and organizational agility: risk uncertainty, and strategy in the innovation economy. Calif. Manage. Rev. 58, 13-35.

Thinktur, 2016. Tendencias Tecnológias en Turismo para 2016. Plataforma Tecnológica de Turismo, Spain. http://www.thinktur.org/media/Ebook_Tendencias_Tec Turismo 2016.pdf.

Turner, M.J., Way, S.A., Hodari, D., Witteman, W., 2017. Hotel property performance: the role of strategic management accounting. Int. J. Hosp. Manage. 63, 33-43.

Yin-Hsi, L., 2012. Managerial capabilities, organizational culture and organizational performance: the resource-based perspective in chinese lodging industry. J. Int. Manage. Stud. 7 (1), 151-157. 